\title{
Uncovered Interest Parity and Monetary Policy Freedom in Countries with the Highest Degree of Financial Openness
}

\author{
Yuniarto Hadiwibowo \\ Graduate School for International Development and Cooperation, Hiroshima University \\ and \\ Ministry of Finance of the Republic of Indonesia \\ E-mail: yhadiwibowo@gmail.com
}

\begin{abstract}
This study reviews the uncovered interest parity hypothesis in perfectly open economies. To meet the assumption of perfect capital mobility, we only include countries and periods with the highest degree of capital account openness in the sample. Using several specifications from the restricted to the less restricted models, we estimate the relationship among exchange rate, domestic and benchmark interest rates. Regardless of the exchange rate regime, we find evidence that domestic interest rate is highly sensitive to international interest rate. Therefore, monetary policy independence would be affected.
\end{abstract}

Keywords: Uncovered interest parity, Monetary policy, Exchange rate, Capital account openness

\section{Introduction}

Uncovered interest parity (UIP) is an important building block of many theoretical models, but a vast number of empirical tests fail to find supporting evidence (Alper et al., 2009). In addition to the existence of arbitrage, commonly UIP is tested jointly with three more assumptions, i.e. free capital mobility, rational (unbiased) expectation and risk neutrality. The failure of these assumptions may contribute to the failure of UIP test (Montiel, 1994).

First, capital account may not always be as open as assumed. When capital is not freely mobile, exchange rate and interest rate may not adjust to the return differentials. Secondly, UIP may also fail because of the failure of the rational expectation. Because of the data availability, the expected exchange rate is usually set to the ex-post exchange rate. If exchange rate is determined by other factors, the use of ex-post exchange rate could cause the deviations from UIP. Finally, the different risk perceptions between domestic and foreign interest rates may also influence the evidence.

This study uses several empirical methods to review the UIP concept. The capital account openness assumption could not be tested independently because it is inherent in the UIP concept. Therefore, we limit the sample only for countries and periods with the highest degree of capital account openness to maintain the free capital mobility assumption. Risk neutrality is another component of the UIP. By restricting the sample to ensure capital account openness, we may test the risk neutrality part of the UIP together with the rational expectation.

The rest of the paper is organized as follows. Section 2 presents the methodology. The result and discussion are presented in Section 3. Finally, section 4 concludes.

\section{Methodology and Data}

If capital is freely mobile, the existence of arbitrage equates domestic and foreign return. UIP hypothesis can be expressed as the relationship among domestic interest rate $\left(\mathrm{id}_{\mathrm{t}}\right)$, foreign interest rate $\left(\mathrm{if}_{\mathrm{t}}\right)$ and expected depreciation $\left(\mathrm{s}_{\mathrm{t}+1} / \mathrm{s}_{\mathrm{t}}\right)$ :

$$
\left(1+i d_{t}\right)=\left(1+i f_{t}\right) \cdot \frac{s_{t+1}}{s_{t}}
$$

or in logarithmic terms

$$
\operatorname{lrd} d_{t}=\operatorname{lrf} f_{t}+l f x_{t}
$$

where lrd denotes domestic return, lrf is foreign return and lf $\mathrm{x}$ is expected depreciation.

We test this relationship using several econometric models as follow:

$$
\begin{aligned}
& \text { lf } x_{t}=\alpha+\beta \cdot\left(\operatorname{lr} d_{t}-\operatorname{lrf} f_{t}\right)+\varepsilon \\
& \operatorname{lrd} d_{t}-l f x_{t}=\alpha+\beta \cdot \operatorname{lrf} f_{t}+\varepsilon \\
& l f x_{t}=\alpha+\beta_{1} \cdot \operatorname{lr} d_{t}+\beta_{2} \cdot \operatorname{lrf} f_{t}+\varepsilon \\
& \operatorname{lr} d_{t}=\alpha+\beta_{1} \cdot \operatorname{lr} f_{t}+\beta_{2} \cdot \operatorname{lf} x_{t}+\varepsilon
\end{aligned}
$$

Flood and Rose (2002) and Chinn (2006) estimate Eq. (3) as the test for UIP with the null hypothesis of $\beta=1$. Foreign exchange market efficiency is the focus of attention. Without reliable estimates of the expected exchange rate, empirical literatures usually use ex-post exchange rate. Therefore, this model is testing the joint hypotheses of 
UIP and rational expectation. The rejection of the null hypothesis might be caused by several factors. Besides the openness of the capital account, the exchange market inefficiency or other factors may affect the exchange rate movement. Next, there might be different risk perception for the increase of domestic and foreign interest rate. Moreover, if the exchange rate regime is hard peg or credibly managed, the expected depreciation would be zero, constant or exogenously determined by the central bank. In this case, putting the expected depreciation as dependent variable would be inappropriate. Therefore, the cause of the deviation in this specification may vary.

Frankel and Okongwu (1995) employ Eq. (4) to measure the perfect substitutability between domestic and foreign assets with the null hypothesis of $\beta=1$. In this specification, the focus is on the expected local assets returns. In this specification, expected depreciation is combined into domestic return. In this case, the estimation on the hard peg or managed regime would be possible. However, the problem with rational expectation may still affect the dependent variable.

The last two equations are less restricted than the previous two in the sense that each parameter is allowed to be different. Eq. (5) corresponds to Eq. (3) if we put restriction $\beta_{2}=-\beta_{1}$. The difference is that Eq. (5) allows different impacts of domestic and foreign interest rate. We may obtain evidence of the foreign exchange market efficiency or the rational expectation hypothesis if this specification could establish significant relationship. If the parameters of domestic and foreign interest are different, it may imply the difference in the perceived risk between domestic and foreign interest rates.

Eq. (6) distinguishes the impacts of foreign interest rate and expected depreciation. Eq. (4) corresponds to restriction $\beta_{2}=1$ in Eq. (6). In this sense, we could get the relationship between domestic and benchmark interest rate separately from the expected depreciation. We focus our attention on $\beta_{1}$ and $\beta_{2}$. If domestic interest rates follow the movement of the benchmark rates, $\beta_{1}$ should equal to unity.

In addition, we also apply dynamic specification to estimate short-run and long-run relationships:

$$
\Delta l r d_{t}=\alpha+\beta_{1} \cdot \Delta l r f_{t}+\beta_{2} \cdot \Delta l f x_{t}+\theta \cdot\left(\operatorname{lrd} d_{t-1}-\gamma_{1} \cdot \operatorname{lrf} f_{t-1}-\gamma_{2} \cdot l f x_{t-1}\right)+\varepsilon_{t}
$$

In this specification, $\beta$ indicates the short-run relationship and $\gamma$ signifies long-run or level relationship. The parameter $\theta$ measures speed of adjustment of domestic interest rate towards the long-run equilibrium. If domestic interest rate responds to minimize deviations from the long-run equilibrium, $\theta$ should be negative.

This paper employs data from International Financial Statistics of the International Monetary Fund. Additional interest rate data are also obtained from the Central Bank of Denmark and Bank Indonesia. We use monthly money market rates for domestic rates $(60 \mathrm{~B} . . \mathrm{ZF}$...) because they reflect the market forces better than other rates. For the benchmark rate, we use U.S. Treasury Bill rate (Note 1). Ex-post exchange rates are used because the appropriate ex-ante expectations of future exchange rates are unobservable. Exchange rates are expressed in terms of domestic currency per U.S. dollars.

As the sample, we choose countries and periods with the highest degree of the openness of the capital account according to KAOPEN index of Chinn and Ito (2008). The sample coverage is dictated by the availability of the data. We include countries with more than nine years of data. The final sample consists of 18 countries. Based on the actual exchange rate following Levy-Yeyati and Sturzenegger (2005) and Frankel et al. (2004), we classify Bahrain, Hong Kong, Indonesia and Lithuania under the managed regime and other fourteen countries under the floating regime.

\section{Result and Discussion}

First, we plot domestic interest rates with benchmark interest rates for each country (Figure 1). The periods and scale for each country is different. We only include the periods with the highest degree of capital account openness in each country. From the figure, we may see that the movements of the domestic interest rates are quite similar with the benchmark interest rate in some countries.

The result is presented in Table 1-3. The dataset is the same. Therefore, we only put the information on the period and number of observation in the first table. The standard errors are robust to both heteroskedasticity and autocorrelation. The upper part shows the estimation on a country-by-country basis. The lower part pools the data across countries.

Table 1 presents the results from Eq. (3) and Eq. (4). We start with the Eq. (3) which is commonly used in UIP test. The result is similar with the previous literatures. The coefficients of interest differentials are not significant in almost all countries. Only one has positive and significant value of $\beta$. In the pooled analysis, managed regime has positive value of $\beta$, while floating regime has marginally significant negative value of $\beta$.

Foreign interest rates do not have significant relationships with the domestic returns adjusted for expected depreciation in the next model (Eq. (4)), except in three countries. Two countries are under managed regime, Bahrain with hard peg and Hong Kong with Currency Board System. Another one is Canada with floating regime.

Eq. (5) also fails to provide the expected results (Table 2). Two countries have only weakly significant coefficient of domestic interest, one of them has the incorrect sign. All significant coefficients of the benchmark rate have the incorrect sign. Pooled analysis produces significant parameters, but the sign is also incorrect. 
The results of the Eq. (3) and Eq. (5) indicate that foreign exchange market is not efficient or at least does not respond to changes in domestic and benchmark interest rates as expected. The movement of the exchange rate is determined by factors other than interest rates.

The fourth model (Eq. (6)) reveals interesting results. Except for two countries, the coefficient of foreign interest rate is positive and highly significant in all countries. In the pooled estimates, we find that the slopes are not statistically different from unity. The hypotheses of $\beta=1$ could not be rejected with $5 \%$ confidence level. However, the coefficients of exchange rate are not significantly different from zero in all individual countries and pooled estimates.

Table 3 presents the results of dynamic specification (Eq. (7)). All coefficient of the foreign interest rate is positive with 13 out of 18 are significant. Pooled data estimates are also significant and not statistically different from unity in both managed and floating regimes. However, the managed regimes seem to adjust more rapidly with half-life of 1 month compared to the floating regimes with half-life of five months. Moreover, floating regimes have smaller $\mathrm{R}^{2}$ value than managed regimes. This implies that factors other than the international interest rate have more influence on floating regimes than managed regimes.

Although the objectives and variables are not exactly the same, our results are in line with Frankel et al. (2004) and Shambaugh (2004). They find that interest rates are converging in the long-run, regardless of the foreign exchange regime. The differences between fixed and floating regime are on the adjustment speed and $\mathrm{R}^{2}$ value.

The results indicate that domestic interest rates follow the movement of benchmark interest rates, but exchange rates do not adjust to this movement. In this case, monetary policy freedom would be affected. However, this should not be interpreted that the expected depreciations do not matter at all. Domestic interest rates may adjust according to the ex ante expected depreciation, but may not reflect the ex post depreciation. On the contrary, exchange rate may be determined by other factors. Therefore, deviations from the interest rates' predicted value may happen.

\section{Conclusions}

This study uses several empirical methods to test the UIP hypothesis. To emulate the perfect capital mobility, we include only countries and periods with the highest degree of capital account openness in the sample. We find that exchange rates do not reflect domestic and international returns. However, we find close long-run relationships between domestic and international interest rates. UIP hypothesis holds in the sense that domestic interest rates adjust to the benchmark interest rate. It applies regardless of the currency regime. Therefore, a complete monetary policy freedom might not be attainable.

\section{Acknowledgement}

The author would like to thank Prof. Komatsu Masaaki for invaluable comments and support.

\section{References}

Alper, C. E., Ardic, O. P. \& Fendoglu, S. (2009). The economics of the uncovered interest parity condition for emerging market. Journal of Economic Surveys, 23, 115-138.

Chinn, M. D., \& Ito, H. (2008). A new measure of financial openness. Journal of Comparative Policy Analysis: Research and Practice, 10, 309-322.

Chinn, M. D. (2006). The (partial) rehabilitation of interest rate parity in the floating rate era: Longer horizons, alternative expectations, and emerging markets. Journal of International Money and Finance, 25, 7-21.

Engle, R. F. \& Granger, C. W. J. (1987). Co-integration and error correction: Representation, estimation, and testing. Econometrica, 55, 251-276.

Flood, R. P. \& Rose, A. K. (2002). Uncovered interest parity in crisis. IMF Staff Papers, 49, 252-266.

Frankel, J. A. \& Okongwu, C. (1995). Liberalized portfolio capital inflows in emerging markets: Sterilization, expectations, and the incompleteness of interest rate convergence. National Bureau of Economic Research Working Paper, 5156.

Frankel, J. A., Schmukler, S. L. \& Serven, L. (2004). Global transmission of interest rates: monetary independence and currency regime. Journal of International Money and Finance, 23, 701-733.

Levy-Yeyati, E. \& Sturzenegger, F. (2005). Classifying exchange rate regimes: Deeds vs. words. European Economic Review, 49, 1603-1635.

Montiel, P. J. (1994). Capital mobility in developing countries: Some measurement issues and empirical estimates. World Bank Economic Review, 8, 311-350.

Shambaugh, J. C. (2004). The effect of fixed exchange rates on monetary policy. Quarterly Journal of Economics, 119, 301-352.

\section{Notes}

Note 1. Other benchmark rates, such as U.S. LIBOR dollar rate and Fed Rate, are highly correlated with the U.S. Treasury Bill rate. We also experimented with these rates and the results were similar. 
Table 1. Expected depreciation and domestic return adjusted for expected depreciation estimation

\begin{tabular}{|c|c|c|c|c|c|c|c|c|c|c|c|c|c|}
\hline \multirow[b]{2}{*}{ No } & \multirow[b]{2}{*}{ Country } & \multirow[b]{2}{*}{ Period } & \multirow[b]{2}{*}{$\mathbf{T}$} & \multicolumn{5}{|c|}{ If $x_{t}=\alpha+\beta\left(\operatorname{lrd}_{t}-\operatorname{lrf}_{t}\right)$} & \multicolumn{5}{|c|}{$\operatorname{Ird}_{\mathbf{t}}-\mathbf{I f x}_{\mathbf{t}}=\alpha+\beta \operatorname{lrf} \mathbf{t}_{\mathrm{t}}$} \\
\hline & & & & $\alpha$ & & $\beta$ & & $\mathbf{R}^{2}$ & $\alpha$ & & $\beta$ & & $\mathbf{R}^{2}$ \\
\hline \multirow[t]{2}{*}{1} & Australia & 1988:01 - 1998:12 & 132 & 2.95 & & -0.54 & & 0.002 & -3.93 & & 2.14 & & 0.011 \\
\hline & & & & $(4.20)$ & & $(1.01)$ & & & $(10.42)$ & & $(2.01)$ & & \\
\hline \multirow[t]{2}{*}{2} & Bahrain & 1985:07 - 2006:12 & 258 & 0.00 & & 0.00 & & 0.001 & 0.14 & $* * *$ & 1.14 & $* * *$ & 0.984 \\
\hline & & & & $(.00)$ & & $(.00)$ & & & $(.06)$ & & $(.01)$ & & \\
\hline \multirow[t]{2}{*}{3} & Canada & 1975:01 - 2008:06 & 402 & 1.03 & & -0.62 & & 0.004 & 2.94 & & 0.75 & $* *$ & 0.013 \\
\hline & & & & $(1.30)$ & & (.45) & & & $(2.52)$ & & $(.33)$ & & \\
\hline \multirow[t]{2}{*}{4} & Denmark & 1992:01 - 2008:06 & 198 & -1.27 & & -0.38 & & 0.001 & 13.83 & $* *$ & -1.98 & & 0.009 \\
\hline & & & & (2.44) & & (.98) & & & (5.97) & & (1.49) & & \\
\hline \multirow[t]{2}{*}{5} & Euro & 1999:01 - 2008:06 & 114 & -3.73 & & -4.54 & $* *$ & 0.042 & 16.01 & ** & -2.90 & & 0.025 \\
\hline & & & & $(2.95)$ & & $(2.00)$ & & & (6.69) & & (1.86) & & \\
\hline \multirow[t]{2}{*}{6} & Germany & 1970:01 - 1998:11 & 347 & -3.07 & & -0.53 & & 0.002 & 14.28 & ** & -0.81 & & 0.003 \\
\hline & & & & (2.29) & & $(.84)$ & & & (5.93) & & $(.85)$ & & \\
\hline \multirow[t]{2}{*}{7} & Hong Kong & 1994:01 - 2008:06 & 174 & 0.07 & & -0.02 & & 0.000 & -0.57 & & 1.16 & *** & 0.501 \\
\hline & & & & (.09) & & $(.05)$ & & & (.43) & & (.11) & & \\
\hline \multirow[t]{2}{*}{8} & Indonesia & 1983:01 - 1995:12 & 156 & 5.91 & & 0.49 & & 0.002 & 6.66 & & -0.46 & & 0.000 \\
\hline & & & & $(3.83)$ & & (.63) & & & $(8.13)$ & & (1.37) & & \\
\hline \multirow[t]{2}{*}{9} & Japan & 1983:01 - 1994:12 & 144 & -10.66 & $* * *$ & -2.76 & & 0.019 & 21.94 & $* *$ & -1.50 & & 0.007 \\
\hline & & & & $(4.08)$ & & $(1.80)$ & & & $(8.95)$ & & $(1.40)$ & & \\
\hline \multirow[t]{2}{*}{10} & Kuwait & 1979:01 - 1990:06 & 138 & 0.19 & & -0.44 & & 0.004 & 7.04 & & 0.09 & & 0.000 \\
\hline & & & & (1.27) & & $(.56)$ & & & (4.66) & & (.46) & & \\
\hline \multirow[t]{2}{*}{11} & Lithuania & 1998:01 - 2008:06 & 126 & -5.63 & $* * *$ & -0.11 & & 0.000 & 14.11 & ** & -1.49 & & 0.012 \\
\hline & & & & (2.13) & & $(.78)$ & & & $(5.87)$ & & $(1.24)$ & & \\
\hline \multirow[t]{2}{*}{12} & Malaysia & 1982:01 - 1992:12 & 132 & 0.93 & & -0.31 & & 0.005 & 10.38 & * & -0.78 & & 0.014 \\
\hline & & & & $(1.71)$ & & (.49) & & & $(5.84)$ & & $(.70)$ & & \\
\hline \multirow[t]{2}{*}{13} & Netherlands & 1981:01 - 1998:11 & 215 & -1.86 & & -1.40 & & 0.009 & 11.18 & & -0.58 & & 0.002 \\
\hline & & & & (3.10) & & (1.18) & & & (7.67) & & (1.09) & & \\
\hline \multirow[t]{2}{*}{14} & New Zealand & 1988:01 - 2008:06 & 246 & 0.19 & & -0.18 & & 0.000 & 16.24 & $* * *$ & -1.80 & & 0.010 \\
\hline & & & & $(4.39)$ & & $(1.00)$ & & & $(5.60)$ & & $(1.15)$ & & \\
\hline 15 & Peru & 1997:01 - 2008:06 & 138 & -1.88 & & 0.55 & $* *$ & 0.031 & 4.05 & & 0.94 & & 0.009 \\
\hline & & & & (1.73) & & (.24) & & & $(2.81)$ & & (.63) & & \\
\hline 16 & Singapore & 1982:01 - 2008:06 & 318 & -3.91 & $* *$ & -1.60 & * & 0.011 & 3.52 & * & 0.35 & & 0.002 \\
\hline & & & & $(1.91)$ & & $(.88)$ & & & $(1.82)$ & & $(.32)$ & & \\
\hline 17 & UK & 1983:01 - 2008:06 & 306 & 2.70 & & -1.44 & & 0.008 & 6.66 & & 0.38 & & 0.001 \\
\hline & & & & $(2.81)$ & & $(1.22)$ & & & $(5.22)$ & & (1.11) & & \\
\hline 18 & Vanuatu & $1986: 05-1998: 12$ & 152 & 1.35 & & 0.14 & & 0.000 & 3.74 & & 0.25 & & 0.000 \\
\hline & & & & (3.12) & & $(1.45)$ & & & $(8.73)$ & & $(1.72)$ & & \\
\hline Poo & & & & & & & & & & & & & \\
\hline & Managed Regime & & 714 & 0.38 & * & 0.37 & $* * *$ & 0.041 & 3.76 & $*$ & 0.34 & & 0.007 \\
\hline & (4 countries) & & & $(.21)$ & & (.12) & & & $(2.26)$ & & (.49) & & \\
\hline & Floating Regime & & 2982 & -0.62 & $* * *$ & -0.52 & $*$ & 0.006 & 8.35 & $* * *$ & -0.16 & & 0.003 \\
\hline & (14 countries) & & & $(.23)$ & & $(.27)$ & & & $(1.58)$ & & $(.28)$ & & \\
\hline & All Countries & & 3696 & -0.25 & & -0.40 & * & 0.011 & 7.56 & $* * *$ & -0.10 & & 0.005 \\
\hline & (18 countries) & & & $(.25)$ & & $(.24)$ & & & (1.37) & & $(.25)$ & & \\
\hline
\end{tabular}

Notes: *,** and $* * *$ represent $10 \%, 5 \%$ and $1 \%$ levels of significance, respectively. Standard errors reported in parentheses are robust to heteroskedasticity and autocorrelation. 
Table 2. Less restricted specification for expected depreciation and domestic return estimation

\begin{tabular}{|c|c|c|c|c|c|c|c|c|c|c|c|c|c|c|c|}
\hline \multirow{3}{*}{$\begin{array}{r}\text { No } \\
1\end{array}$} & \multirow{3}{*}{$\begin{array}{c}\text { Country } \\
\text { Australia }\end{array}$} & \multicolumn{7}{|c|}{ Ifx $x_{t}=\alpha+\beta_{1} \operatorname{Ird}_{t}+\beta_{2} \operatorname{Irf}_{t}$} & \multicolumn{7}{|c|}{$\operatorname{Ird}_{t}=\alpha+\beta_{1} \operatorname{lrf}_{t}+\beta_{2} \mathbf{I f x _ { t }}$} \\
\hline & & \multicolumn{2}{|l|}{$\alpha$} & \multicolumn{2}{|c|}{$\beta_{1}$} & \multicolumn{2}{|l|}{$\beta_{2}$} & \multirow{3}{*}{$\frac{\mathbf{R}^{2}}{0.006}$} & \multicolumn{2}{|c|}{$\alpha$} & \multicolumn{2}{|c|}{$\beta_{1}$} & \multicolumn{2}{|l|}{$\beta_{2}$} & \multirow{2}{*}{$\frac{\mathbf{R}^{2}}{0.78}$} \\
\hline & & -4.47 & & -1.32 & & 3.20 & & & -3.62 & $* * *$ & 2.30 & $* * *$ & -0.01 & & \\
\hline & & (12.15) & & (1.37) & & (3.97) & & & (1.11) & & $(.20)$ & & $(.01)$ & & \\
\hline \multirow[t]{2}{*}{2} & Bahrain & 0.00 & & 0.00 & & 0.00 & & 0.003 & 0.15 & $* * *$ & 1.14 & $* * *$ & -0.67 & & 0.984 \\
\hline & & $(.00)$ & & $(.00)$ & & $(.00)$ & & & $(.06)$ & & $(.01)$ & & (1.69) & & \\
\hline \multirow[t]{2}{*}{3} & Canada & -1.72 & & -0.79 & * & 1.31 & $* *$ & 0.010 & 0.67 & * & 1.15 & $* * *$ & -0.01 & & 0.766 \\
\hline & & (2.53) & & (.45) & & $(.59)$ & & & $(.36)$ & & $(.06)$ & & $(.01)$ & & \\
\hline \multirow[t]{2}{*}{4} & Denmark & -10.47 & & 0.14 & & 2.17 & & 0.011 & 3.89 & $* * *$ & 0.22 & & 0.00 & & 0.017 \\
\hline & & $(6.85)$ & & $(1.04)$ & & $(1.52)$ & & & $(.96)$ & & (.18) & & $(.01)$ & & \\
\hline \multirow[t]{2}{*}{5} & Euro & -4.21 & & -4.39 & & 4.54 & $* *$ & 0.042 & 2.15 & $* * *$ & 0.31 & $* * *$ & 0.00 & & 0.319 \\
\hline & & (11.44) & & (3.94) & & (1.99) & & & $(.26)$ & & $(.07)$ & & $(.00)$ & & \\
\hline \multirow[t]{2}{*}{6} & Germany & -11.50 & $*$ & 0.18 & & 1.14 & & 0.007 & 3.41 & $* * *$ & 0.40 & $* * *$ & 0.00 & & 0.176 \\
\hline & & (6.56) & & $(.97)$ & & $(.95)$ & & & $(.79)$ & & $(.10)$ & & $(.00)$ & & \\
\hline \multirow[t]{2}{*}{7} & Hong Kong & -0.10 & & -0.04 & & 0.08 & & 0.003 & -0.66 & $* *$ & 1.21 & $* * *$ & -0.03 & & 0.710 \\
\hline & & (.27) & & $(.06)$ & & (.10) & & & $(.28)$ & & $(.07)$ & & $(.05)$ & & \\
\hline \multirow[t]{2}{*}{8} & Indonesia & -3.14 & & 0.55 & & 0.84 & & 0.005 & 7.74 & $* * *$ & 0.84 & $* * *$ & 0.00 & & 0.159 \\
\hline & & (12.30) & & (.73) & & (.94) & & & (1.69) & & (.29) & & $(.00)$ & & \\
\hline 9 & Japan & -14.96 & & -2.23 & & 3.01 & $*$ & 0.020 & 2.09 & $* * *$ & 0.47 & $* * *$ & 0.00 & & 0.310 \\
\hline & & $(9.70)$ & & $(2.31)$ & & (1.76) & & & $(.63)$ & & $(.08)$ & & $(.00)$ & & \\
\hline 10 & Kuwait & -3.78 & & 0.07 & & 0.41 & & 0.009 & 3.50 & $* * *$ & 0.54 & $* * *$ & 0.00 & & 0.565 \\
\hline & & (5.18) & & (.62) & & $(.53)$ & & & (.67) & & $(.08)$ & & $(.01)$ & & \\
\hline 11 & Lithuania & -13.87 & ** & 0.80 & & 1.61 & & 0.026 & 1.27 & $* * *$ & 0.62 & $* * *$ & 0.00 & & 0.324 \\
\hline & & (6.57) & & (.94) & & (1.10) & & & (.34) & & (.12) & & $(.00)$ & & \\
\hline 12 & Malaysia & -4.53 & & 0.08 & & 0.74 & & 0.013 & 6.36 & $* * *$ & -0.04 & & 0.00 & & 0.002 \\
\hline & & $(5.93)$ & & $(.57)$ & & $(.70)$ & & & (1.19) & & (.14) & & $(.02)$ & & \\
\hline 13 & Netherlands & -2.39 & & -1.35 & & 1.43 & & 0.009 & 3.71 & $* * *$ & 0.37 & $* * *$ & 0.00 & & 0.194 \\
\hline & & $(8.41)$ & & $(1.51)$ & & $(1.24)$ & & & (.98) & & $(.12)$ & & $(.00)$ & & \\
\hline 14 & New Zealand & -11.81 & $* *$ & -0.50 & & 3.49 & $*$ & 0.028 & 2.93 & $* * *$ & 1.13 & $* * *$ & 0.00 & & 0.521 \\
\hline & & $(5.55)$ & & (.99) & & $(1.82)$ & & & (.53) & & (.13) & & $(.00)$ & & \\
\hline 15 & Peru & -4.16 & & 0.46 & * & 0.30 & & 0.035 & -0.03 & & 2.24 & $* * *$ & 0.04 & & 0.384 \\
\hline & & $(2.79)$ & & $(.27)$ & & $(.83)$ & & & (.64) & & $(.30)$ & & $(.03)$ & & \\
\hline 16 & Singapore & -3.86 & $* *$ & -1.61 & & 1.60 & * & 0.011 & -0.15 & & 0.75 & $* * *$ & -0.01 & & 0.774 \\
\hline & & (1.79) & & $(1.21)$ & & $(.91)$ & & & (.19) & & $(.04)$ & & $(.00)$ & & \\
\hline 17 & UK & -1.13 & & -1.50 & & 2.30 & & 0.011 & 2.18 & $* * *$ & 1.08 & $* * *$ & -0.01 & & 0.540 \\
\hline & & $(4.89)$ & & $(1.24)$ & & (1.71) & & & $(.55)$ & & (.13) & & $(.01)$ & & \\
\hline 18 & Vanuatu & 0.65 & & 0.22 & & -0.11 & & 0.000 & 5.63 & $* * *$ & 0.19 & $* * *$ & 0.00 & & 0.073 \\
\hline & & (10.04) & & $(1.26)$ & & $(1.78)$ & & & $(.40)$ & & $(.05)$ & & $(.00)$ & & \\
\hline Poo & & & & & & & & & & & & & & & \\
\hline & Managed Regime & -2.63 & & 0.37 & $* * *$ & 0.29 & & 0.043 & 1.80 & $* * *$ & 1.00 & $* * *$ & 0.00 & $* * *$ & 0.796 \\
\hline & (4 countries) & (2.13) & & $(.14)$ & & $(.38)$ & & & (.44) & & (.10) & & $(.00)$ & & \\
\hline & Floating Regime & -5.54 & $* * *$ & -0.35 & & 1.21 & $* * *$ & 0.011 & 2.06 & $* * *$ & 0.78 & $* * *$ & 0.00 & $*$ & 0.493 \\
\hline & (14 countries) & $(1.30)$ & & $(.25)$ & & $(.22)$ & & & $(.73)$ & & $(.13)$ & & $(.00)$ & & \\
\hline & All Countries & -4.98 & $* * *$ & -0.25 & & 1.10 & $* * *$ & 0.015 & 2.06 & $* * *$ & 0.81 & $* * *$ & 0.00 & & 0.581 \\
\hline & (18 countries) & $(1.15)$ & & $(.22)$ & & $(.20)$ & & & (.62) & & (.12) & & $(.00)$ & & \\
\hline
\end{tabular}

Notes: ${ }^{*}, *$ and $* * *$ represent $10 \%, 5 \%$ and $1 \%$ levels of significance, respectively. Standard errors reported in parentheses are robust to

heteroskedasticity and autocorrelation. 
Table 3. Dynamic specification

\begin{tabular}{|c|c|c|c|c|c|c|c|c|c|c|c|c|c|c|}
\hline \multirow{4}{*}{$\begin{array}{r}\text { No } \\
1\end{array}$} & \multirow{4}{*}{$\begin{array}{l}\text { Country } \\
\text { Australia }\end{array}$} & \multicolumn{13}{|c|}{ 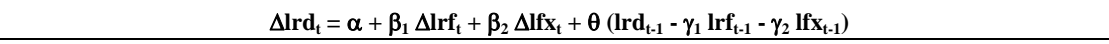 } \\
\hline & & \multicolumn{2}{|c|}{$\alpha$} & \multicolumn{2}{|c|}{$\beta_{1}$} & \multicolumn{2}{|c|}{$\beta_{2}$} & \multicolumn{2}{|c|}{$\theta$} & \multicolumn{2}{|c|}{$\gamma_{1}$} & \multicolumn{2}{|l|}{$\gamma_{2}$} & \multirow{2}{*}{$\frac{\mathbf{R}^{2}}{0.315}$} \\
\hline & & -0.37 & $* * *$ & 0.78 & $* * *$ & 0.00 & & -0.04 & ** & 3.12 & $* * *$ & -0.05 & & \\
\hline & & (.13) & & (.15) & & $(.00)$ & & $(.02)$ & & $(.92)$ & & $(.03)$ & & \\
\hline \multirow[t]{2}{*}{2} & Bahrain & 0.06 & $* *$ & 1.05 & $* * *$ & -0.25 & & -0.42 & $* * *$ & 1.13 & $* * *$ & 12.82 & $* * *$ & 0.481 \\
\hline & & $(.03)$ & & (.09) & & (.88) & & $(.06)$ & & $(.02)$ & & (4.79) & & \\
\hline \multirow[t]{2}{*}{3} & Canada & -0.06 & & 0.03 & & -0.01 & * & -0.27 & $* * *$ & 1.29 & $* * *$ & -0.02 & $* *$ & 0.226 \\
\hline & & (.11) & & (.13) & & $(.00)$ & & $(.07)$ & & $(.07)$ & & $(.01)$ & & \\
\hline \multirow[t]{2}{*}{4} & Denmark & 0.01 & & 0.03 & & 0.00 & & -0.03 & & 0.99 & & -0.04 & & 0.042 \\
\hline & & $(.08)$ & & (.12) & & $(.00)$ & & $(.04)$ & & $(.60)$ & & $(.04)$ & & \\
\hline \multirow[t]{2}{*}{5} & Euro & -0.07 & * & 0.26 & $* * *$ & 0.00 & & -0.01 & & 5.51 & & -0.07 & & 0.359 \\
\hline & & $(.04)$ & & $(.08)$ & & $(.00)$ & & $(.02)$ & & (14.09) & & $(.22)$ & & \\
\hline \multirow[t]{2}{*}{6} & Germany & 0.28 & & 0.06 & & 0.00 & & -0.12 & $* * *$ & 0.55 & $* * *$ & 0.02 & & 0.072 \\
\hline & & (.19) & & (.10) & & $(.00)$ & & $(.04)$ & & (.13) & & $(.01)$ & & \\
\hline \multirow[t]{2}{*}{7} & Hong Kong & -0.48 & $* *$ & 0.66 & $* * *$ & -0.05 & & -0.61 & $* * *$ & 1.24 & $* * *$ & -0.25 & $* *$ & 0.338 \\
\hline & & (.19) & & (.24) & & $(.04)$ & & $(.14)$ & & $(.08)$ & & (.10) & & \\
\hline \multirow[t]{2}{*}{8} & Indonesia & 3.69 & $* *$ & 1.11 & & 0.00 & & -0.48 & $* * *$ & 0.84 & $* *$ & 0.01 & & 0.249 \\
\hline & & $(1.55)$ & & (1.17) & & $(.00)$ & & (.16) & & (.37) & & $(.01)$ & & \\
\hline \multirow[t]{2}{*}{9} & Japan & -0.16 & ** & 0.12 & $*$ & 0.00 & & -0.04 & * & 1.41 & ** & 0.01 & & 0.105 \\
\hline & & (.07) & & (.07) & & $(.00)$ & & $(.02)$ & & (.62) & & $(.03)$ & & \\
\hline \multirow[t]{2}{*}{10} & Kuwait & 0.52 & * & 0.41 & $* * *$ & 0.00 & & -0.17 & $* * *$ & 0.60 & $* * *$ & 0.05 & * & 0.294 \\
\hline & & $(.28)$ & & (.10) & & $(.00)$ & & $(.05)$ & & (.18) & & $(.03)$ & & \\
\hline 11 & Lithuania & 0.30 & * & -0.71 & & 0.00 & & -0.31 & $* * *$ & 0.67 & $* * *$ & 0.00 & & 0.187 \\
\hline & & (.16) & & (.46) & & $(.00)$ & & $(.08)$ & & $(.16)$ & & $(.01)$ & & \\
\hline 12 & Malaysia & 0.97 & & -0.31 & & 0.00 & & -0.20 & $* * *$ & 0.15 & & 0.05 & & 0.112 \\
\hline & & $(.60)$ & & $(.28)$ & & $(.01)$ & & $(.07)$ & & $(.25)$ & & $(.05)$ & & \\
\hline 13 & Netherlands & -0.07 & & 0.16 & $* * *$ & 0.00 & & -0.02 & & 1.21 & & -0.04 & & 0.067 \\
\hline & & (.13) & & $(.05)$ & & $(.00)$ & & $(.02)$ & & $(1.05)$ & & (.04) & & \\
\hline 14 & New Zealand & 0.14 & & 0.29 & $*$ & 0.00 & * & -0.05 & ** & 1.02 & $* * *$ & -0.05 & & 0.058 \\
\hline & & (.09) & & (.15) & & $(.00)$ & & $(.02)$ & & (.29) & & $(.03)$ & & \\
\hline 15 & Peru & -0.15 & & 0.21 & & -0.01 & & -0.22 & $* * *$ & 2.32 & $* * *$ & 0.11 & & 0.143 \\
\hline & & (.23) & & (.86) & & $(.01)$ & & $(.08)$ & & (.47) & & $(.08)$ & & \\
\hline 16 & Singapore & -0.02 & & 0.23 & & 0.00 & & -0.14 & $* * *$ & 0.75 & $* * *$ & 0.04 & & 0.125 \\
\hline & & $(.06)$ & & (.16) & & $(.00)$ & & $(.04)$ & & (.07) & & (.05) & & \\
\hline 17 & UK & 0.07 & & 0.09 & & 0.00 & & -0.08 & $* * *$ & 1.29 & $* * *$ & 0.01 & & 0.059 \\
\hline & & (.08) & & (.18) & & $(.00)$ & & $(.02)$ & & $(.23)$ & & $(.02)$ & & \\
\hline 18 & Vanuatu & 0.63 & $* *$ & -0.26 & & 0.00 & & -0.11 & $* *$ & 0.17 & & -0.01 & & 0.052 \\
\hline & & (.27) & & (.18) & & $(.00)$ & & $(.05)$ & & $(.16)$ & & $(.02)$ & & \\
\hline Poo & & & & & & & & & & & & & & \\
\hline & Managed Regime & 0.80 & $* * *$ & 0.66 & $* *$ & 0.00 & $* * *$ & -0.46 & $* * *$ & 1.01 & $* * *$ & 0.00 & & 0.238 \\
\hline & ( 4 countries) & (.19) & & (.32) & & $(.00)$ & & $(.03)$ & & (.10) & & $(.00)$ & & \\
\hline & Floating Regime & 0.08 & & 0.18 & $* * *$ & 0.00 & & -0.10 & $* * *$ & 0.99 & $* * *$ & 0.00 & & 0.069 \\
\hline & (14 countries) & $(.08)$ & & $(.06)$ & & $(.00)$ & & $(.02)$ & & $(.15)$ & & $(.01)$ & & \\
\hline & All Countries & 0.20 & & 0.20 & $* * *$ & 0.00 & & -0.15 & $* * *$ & 0.93 & $* * *$ & 0.00 & & 0.090 \\
\hline & (18 countries) & (.13) & & $(.07)$ & & $(.00)$ & & $(.04)$ & & (.13) & & $(.00)$ & & \\
\hline
\end{tabular}

Notes: $* * *$ and $* * *$ represent $10 \%, 5 \%$ and $1 \%$ levels of significance, respectively. Standard errors reported in parentheses are robust to heteroskedasticity and autocorrelation. 

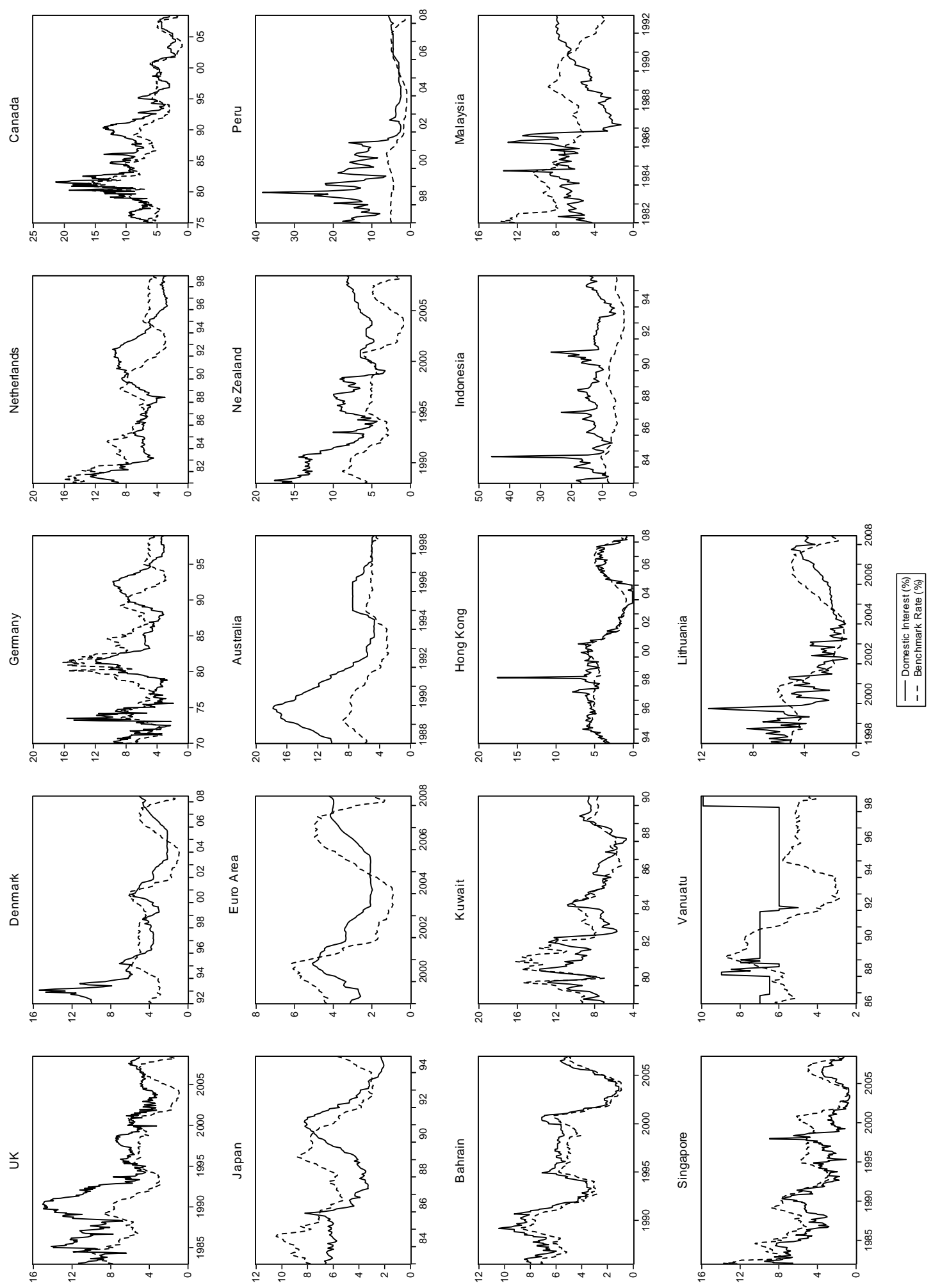

Figure 1. Domestic and Benchmark Interest Rates

Notes: The period and scale for each country are different. 